\title{
Aspects of the Cenozoic stratigraphy of the Northern Sulaiman Ranges, Pakistan
} UK.

\begin{abstract}
The results of micropalaeontological, nannopalaeontological and palynological analyses of Cenozoic sections from the Northern Sulaiman Ranges in Pakistan are discussed. They are in keeping with previously published results (though in some cases significantly more refined). They enable placement of most of the sampled lithostratigraphic units in a global bio- and sequence-stratigraphic framework. Limestones appear to be associated with essentially transgressive global sequences, shales with essentially regressive sequences. Palaeoenvironmental interpretations indicate a range of depositional settings from continental through shallow marine to basinal. A number of shallow marine carbonate platform subenvironments are recognized over the Palaeocene-Eocene section J. Micropalaeontol. 16(1): 51-58, May 1997.
\end{abstract}

\section{INTRODUCTION}

BP has recently undertaken a field survey of part of the Northern Sulaiman Ranges in Pakistan (Fig. 1). The primary objective of the survey was to log selected sections and to collect samples for geochemical, sedimentological and palaeontological analysis in order to identify any resource (source, reservoir and seal) potential. The secondary objective was to obtain enough structural geological information to construct a cross-section through the mountain-front to constrain appropriate source maturation and migration models. Structural aspects are discussed by Banks \& Warburton (1986) and Jadoon et al. (1994)

Samples were made available for palaeontological analysis from the Dunghan, Ghazij, Baska, Kirthar and Chitarwata Formations and the Siwalik Group of the Zam Tower, Zor Shahr, Domanda, Toi River and Baska sections (Fig. 1). Particular emphasis was placed on the Eocene Baska and
Kirthar Formations (Fig. 2), which, by analogy with the Potwar Basin to the northeast (Brown \& Dey, 1975; Khan et al., 1986) were perceived to have the most resource potential.

Micropalaeontological analyses were undertaken by the author (calcareous algae and foraminifera) and John Athersuch (ostracods), nannopalaeontological analyses by Ted Finch and Julie Pearce, and palynological analyses by Bob Ravn, Paul Ventris and John Williams.

\section{RESULTS AND DISCUSSION}

Reults are summarized on Fig. 3, and discussed in more detail (in ascending stratigraphic order) below.

\section{Dunghan Formation}

The dominant lithology was bioclastic limestone. Micropalaeontological analyses were undertaken on three samples $(18,44$ and 45).

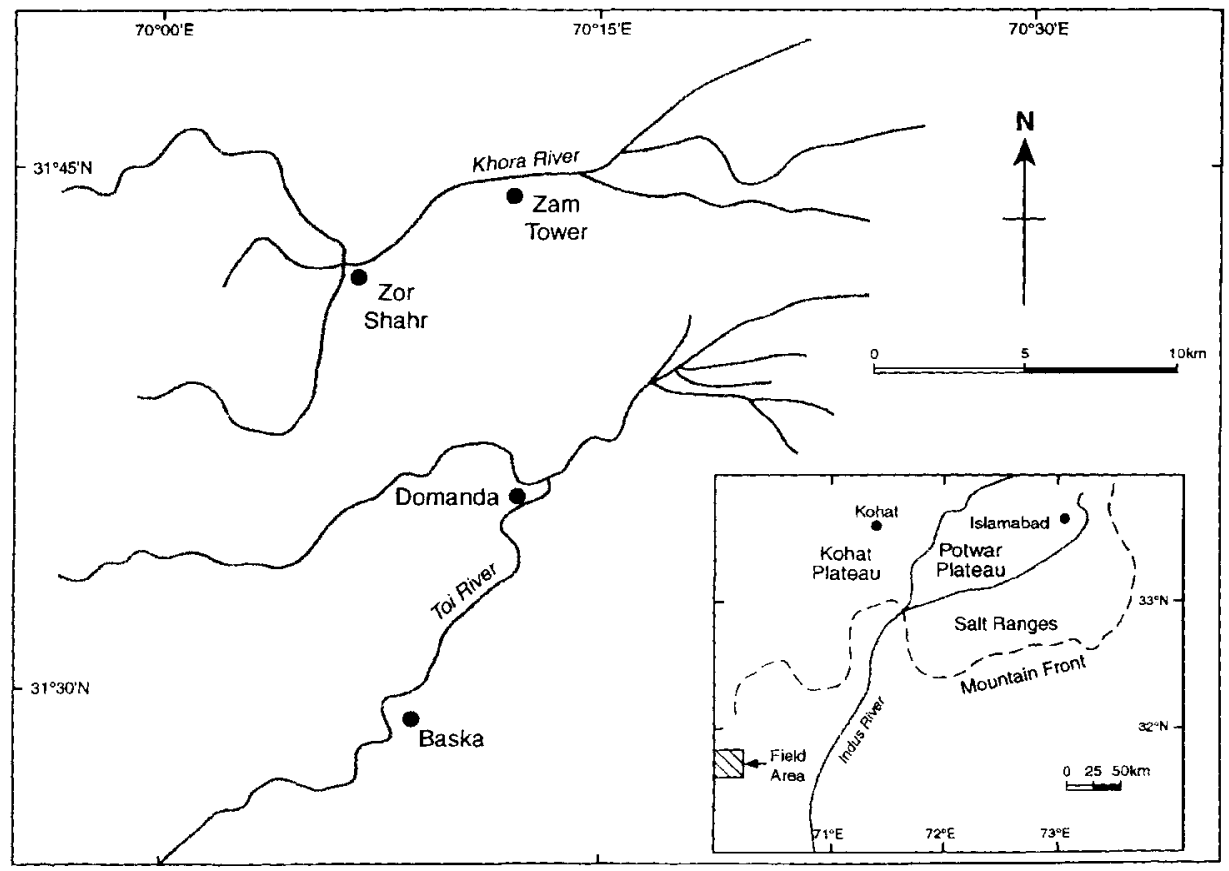

Fig. 1. Location map (1:250000 (inset 1: 2000000$)$ ). 


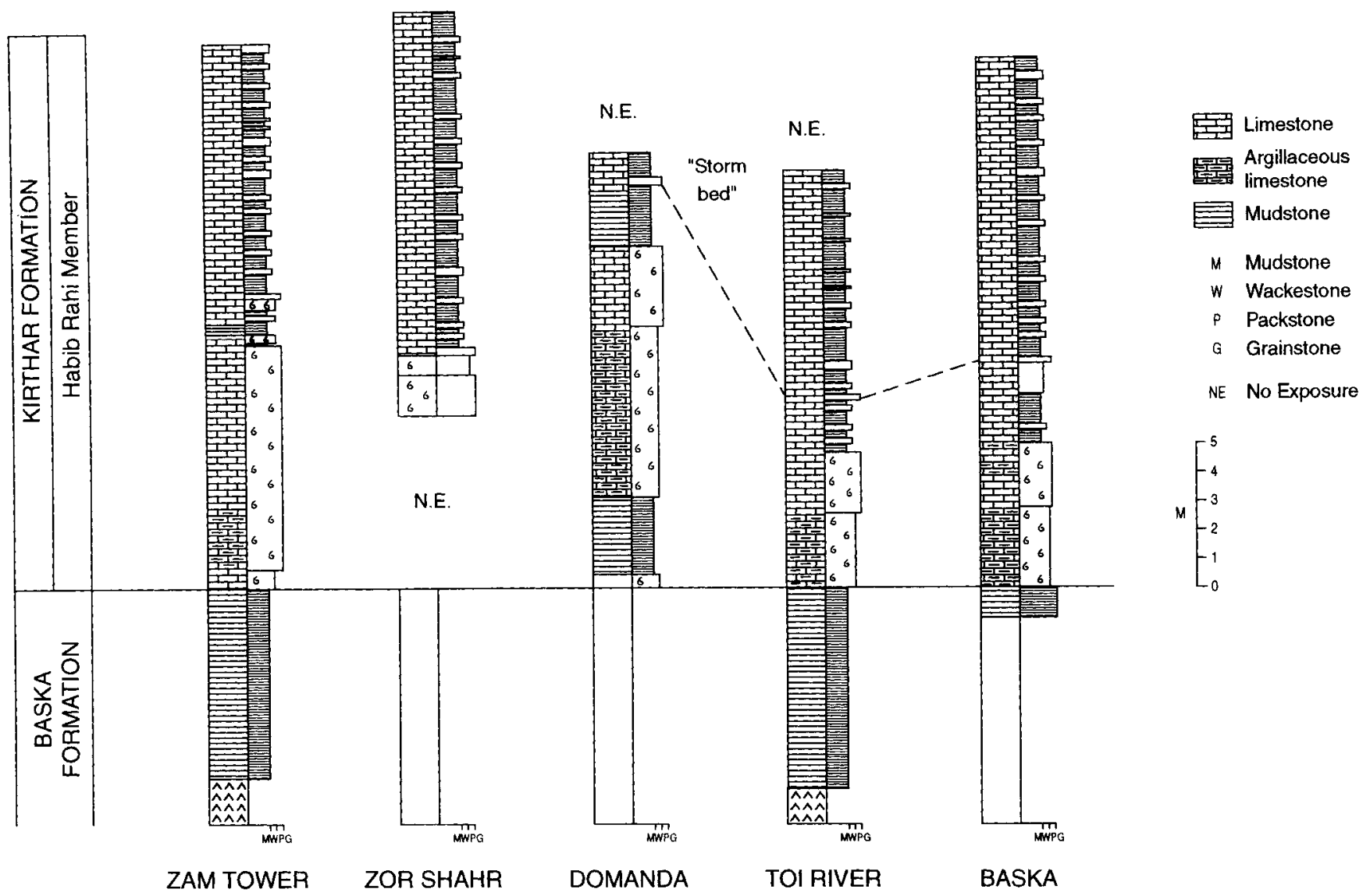

Fig. 2. Measured Baska and Lower Kirthar Formation sections. Samples 47-122 were collected from Zam Tower section, 131-143 from Zor Shahr, 150-158 from Domanda, 174-180 from Toi River and 181-195 from Baska (see Fig. 1). Samples were collected on average every $1 \mathrm{~m}$.

Results. The microfauna is moderately rich and diverse, and included benthonic and planktonic foraminifera, calcareous algae, and bryozoan and miscellaneous macrofossil debris. The benthonic foraminifera include ?Dictyoconus $\mathrm{sp}$. and indeterminate miliolids and rotaliids. The planktonic foraminifera include Globorotalia (Morozovella) ex gr. angulata/conicotruncata, $G$. $(M)$. ex gr. subbotinae and $G$. $(M)$. sp. The calcareous algae include Amphiroa, sp., Archaeolithothamnium, sp., indeterminate codiaceans and dasycladaceans, Distichoplax biserialis, Lithothamnium sp., Mesophyllum and rhodoliths.

Discussion. Stratigraphy - A Late Palaeocene to Early Eocene age is indicated by the occurrences of the planktonic foraminifera Globorotalia (Morozovella) ex gr. angulata/conicotruncata (Zones P3-P5 of Blow, 1979) and and $G$. (M). ex gr. subbotinae
(P6-P8). Published information supports this interpretation (see, for instance, Samanta, 1972, 1973; Kureshy, 1978a, 1984).

Palaeoenvironmental interpretation - Micropalaeontological evidence points to a warm, shallow carbonate platform. The presence of codiacean, dasycladacean and rhodophytic algae indicates a setting within the euphotic zone (no deeper than 5 $15 \mathrm{~m})$.

\section{Ghazij Formation}

The dominant lithology was mudstone. Palynological analyses were undertaken on four samples (46, 120, 124 and 130).

Results. The in situ palynoflora is impoverished, and includes only rare pollen (flowering-plant (angiosperm) and grass (Gramineae) pollen) and spores (Callialasporites). Reworked

Fig. 3. Stratigraphic summary. Bio-, chrono- and sequence stratigraphy from Haq et al. (1987). Lithostratigraphy modified after Hemphill \& Kidwai (1973). Dunghan equivalent to Ranikot and Lower Laki of Eames (1952), Ghazij to Middle Laki, Baska to Upper Laki ('shales with alabaster'), Habib Rahi to 'platy limestone', Domanda to 'lower chocolate clays', Pir Koh to 'white marl band', Drazinda to 'upper chocolate clays', Chitarwata to Murree and Nari. Calibrated global (narrow band) and observed local (broad band) stratigraphic ranges of selected larger benthonic and planktonic foraminifera and calcareous nannoplankton are shown. 
Cenozoic stratigraphy

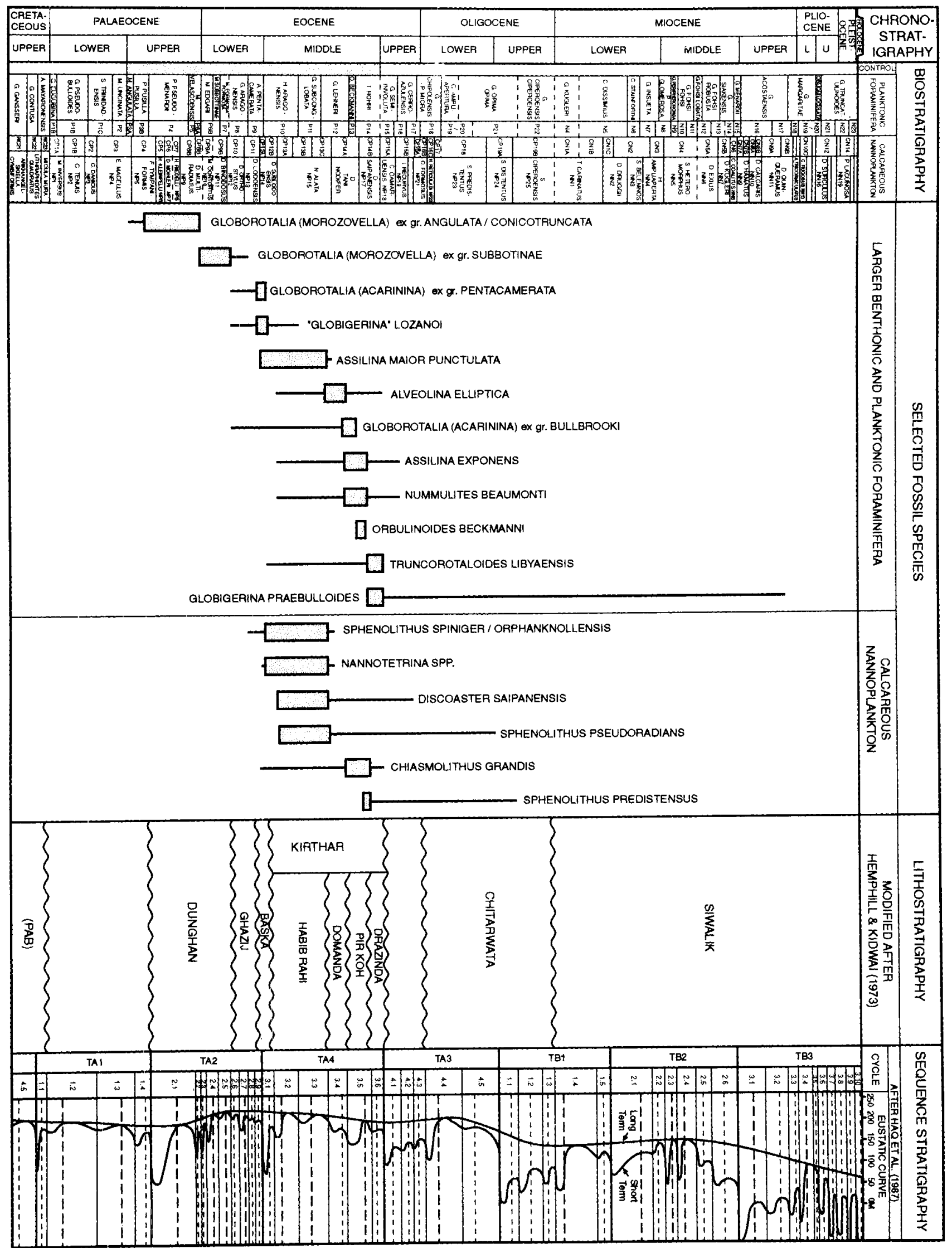


Early Cretaceous dinoflagellate cysts are also present.

Discussion. Stratigraphy - No conclusions can be drawn with regard to age. Published information indicates Early Eocene (see, for instance, Gill, 1953; Haque, 1956; Nagappa, 1959; Latif, 1961; Siddiqui, 1971; Samanta, 1972, 1973; Dorreen, 1974; Kureshy, 1978a,b, 1985a).

Palaeoenvironmental interpretation - The absence of marine palynomorphs provides negative evidence of a non-marine palaeoenvironment.

\section{Baska Formation}

The dominant lithology is mudstone. Micropalaeontological and palynological analyses were undertaken on eight samples $(95,106,108,113,115-116,119$ and 181).

Results. The microfauna is moderately rich and diverse, and includes benthonic and planktonic foraminifera, ostracods, gastropods, and bryozoan, echinoderm and miscellaneous macrofossil debris. The benthonic foraminifera include Miliolida (?Archaias sp., ?Peneroplis sp., Quinqueloculina spp.), Buliminida (Brizalina spp.), smaller Rotaliida (anomalinids, discorbids, Nonion spp.) and larger Rotaliida (Assilina maior punctulata, Dictyoconoides cooki, Nummulites spp.). The planktonic foraminifera (Globigerinida) include 'Globigerina' lozanoi and Globorotalia (Acarinina) ex gr. pentacamerata. The ostracods include Alocopocythere sp., bairdiids, cyprids, Gyrocythere exaggerata, Krithe sp., ?Occulticythereis sp., Pontocythere sp., trachyleberidids and Xestoleberis of. globosa.

The palynofiora is also moderately rich and diverse, and includes marine dinoflagellate cysts and terrestrially derived pollen and spores. The dinocysts include Achomosphaera sp., Areoligera sp., Cordosphaeridium sp., Diphyes cf. colligerum (?D. ficusoides), ?Impletosphaeridium sp., Phthanoperidinium sp., Systematophora placacantha and Thalassiphora sp.

Discussion. Stratigraphy - An age in the range latest Earlyearliest Middle Eocene is indicated by the occurrences of the larger benthonic nummulitid foraminifer Assilina maior punctulata (Cuisien Superieur - Lutetien Basal of Schaub, 1981; calcareous nannoplankton Zones NP14-NP15 of Martini, 1971) and the planktonic foraminifera 'Globigerina' lozanoi (Zones P8-P10 of Blow, 1979) and Globorotalia (Acarinina) ex gr. pentacamerata (P8-?P9). Published information supports this interpretation (see, for instance, Siddiqui, 1971).

The Baska Formation appears to be associated with the essentially regressive global third-order (?eustatically mediated) sequence TA3.1 of Haq et al. (1987).

Palaeoenvironmental interpretation - Microfaunal evidence points to a low-energy back-bank lagoon characterized by Miliolida. The presence of sea-grasses is indicated by the presence of epiphytic discorbids, the influence of the open ocean by rare globigerinids.

The depth of depositional environment is difficult to determine, because it would have been determined not by the foraminifera themselves but by the photosynthetic algal symbionts to which they acted as host. Modern Archaias aduncus, Cyclorbiculina compressa and Peneroplis proteus contain photosynthetic green algae which restrict them to between 0-15m (e.g. Murray, 1973; Reiss \& Hottinger, 1984; Hallock, 1988).

\section{Habib Rahi Limestone Member (Kirthar Formation)}

Lithology ranged from nummulitic and nummulithoclastic grainstone carbonate to laminated shale. Micropalaeontological, nannopalaeontological and palynological analyses were undertaken on 38 samples $(58,59,68,69,80,82,83,85-87,91-$ $94,131,132,136,141-143,150,152,155-157,174-177,179,180$, $182-185,188,194$ and 195). The majority of the micropalaeontological analyses were undertaken on random thin-section samples.

Results. The microfauna is moderately rich and diverse, and included benthonic and planktonic foraminifera, and bivalve, bryozoan and miscellaneous macrofossil debris. The benthonic foraminifera include Buliminida (Brizalina sp., Loxostomum sp., Stainforthia sp., Uvigerinella sp.), smaller Rotaliida (Cibicidoides sp.) and larger Rotaliida (Assilina maior punctulata, Dictyoconoides sp., Discocyclina sp., Lockhartia sp., Nummulites). The planktonic foraminifera (Globigerinida) include indeterminate globigerinids.

The nannofiora is also moderately rich and diverse, and included Braarudosphaera bigelowi, Chiasmolithus grandis, $C$. formosus, Coccolithus eopelagicus, C. pelagicus, Discoaster barbadiensis, D. binodosus, D. deflandrei, D. saipanensis, Helicosphaera lophota, H. seminulum, Lanternithus minutus, Markalius inversus, Micranolithus spp., Nannotetrina spp., Pemma angulatum, $P$. spp., Reticulofenestra dictyoda, Rhabdolithus tenuis, Sphenolithus moriformis, S. pseudoradians, S. radians, S. spiniger/orphanknollensis, S. spp. and Zygrabdlithus bijugatus.

The palynoflora is also moderately rich and diverse, and includes marine dinoflagellate cysts and terrestrially derived pollen and spores. The dinocysts include Achomosphaera sp., ?Cordosphaeridium sp., Diphyes colligerum (?D. ficusoides), ?Impletosphaeridium $\mathrm{sp}$, ?Systematophora $\mathrm{sp}$. and Thalassiphora sp.

Discussion. Stratigraphy - An early Middle Eocene is indicated by the occurrences of the larger benthonic nummulitid foraminifer Assilina maior punctulata (Cuisien Superieur Lutetien Basal of Schaub, 1981; calcareous nannoplankton Zones NP14-NP15 of Martini, 1971) and the calcareous nannofossils Discoaster saipanensis (calcareous nannoplankton Zones NP15-NP20 of Martini, 1971), Nannotetrina spp. (NP14NP15), Sphenolithus pseudoradians (NP15-NP23), and $S$. spiniger/orphanknollensis (Zones NP13-NP15). Published information suggests an essentially Middle-?Late Eocene age for the Kirthar Formation (see, for instance, Gill, 1953; Nagappa, 1959; Latif, 1961; Khan, 1967; Siddiqui, 1971; Samanta, 1972, 1973; Dorreen, 1974; Kureshy, 1978a,b, 1985b).

The Habib Rahi Member appears to be associated with the essentialy transgressive global third-order (?eustatically mediated) sequences TA3.2-TA3.3 of Haq et al. (1987).

Palaeoenvironmental interpretation - Microfaunal evidence points to a range of carbonate platform and associated basinal sub-environments. Proximal high-energy bank and fore-bank (nummulitic and nummulithoclastic grainstone) sub-environments are characterized by Rotaliida (nummulitids and discocyclinids, respectively) (cf. Henson, 1950; Das Gupta, 1975; Ghose, 1977; Decrouez \& Lanterno, 1979; Philobbos \& Keheila, 1979; Benjamini, 1981; Luterbacher, 1984; Reiss \& Hottinger, 1984; Serra Kiel \& Regaunt, 1984; Singh, 1984; Moody, 1987; Pautal, 1987; Hallock, 1988; Buxton \& Pedley, 1989). Distal 


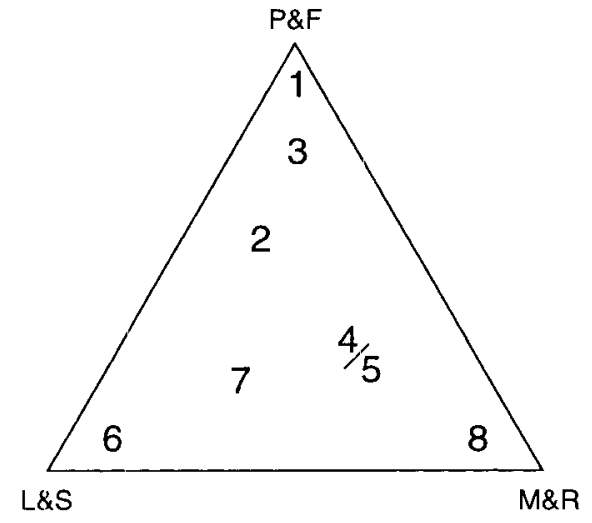

Fig. 4. Ternary plot of foraminiferal 'morphogroups' illustrating discrimination of standard facies (after Hallock \& Glenn, 1986). M \& $\mathrm{R}=$ Miliolicla and smaller Rotaliida; $\mathrm{L} \& \mathrm{~S}=$ lenticular and subspheroidal larger Rotaliida; $P$ \& $F=$ planktonic foraminifera (Globigerinida) and flattened larger Rotaliida. 1-8 $=$ standard facies of Wilson (1975) $(1=$ basin; $2=$ open shelf; $3=$ toe of slope; $4=$ foreslope; $5=$ ecologic reef; $6=$ shelf sand; $7=$ open platform; $8=$ restricted platform). A-form dominated nummulitid populations from the Habib Rahi Member of the Kirthar Formation fall in the 'toe of slope' field.

basinal (laminated shale) sub-environments are characterized by stress-tolerant Buliminida (as in the Palaeogene of Tunisia (Bou Dagher, 1987), large-pored Rotaliida (again as in the Palaeogene of Tunisia (Keller, 1988) and Globigerinida.

The depth of depositional environment is again difficult to determine, because it would have been determined not by the foraminifera themselves but by the photosynthetic algal symbionts to which they acted as host. Modern nummulitids (e.g. Amphistegina, Operculina, Operculinella) contain photosynthetic B-2 and B-3 diatoms whose light requirements are nonspecific and which therefore enable them to range down to the light flocr (usually $\pm 130 \mathrm{~m}$ ) (e.g. Murray, 1973; Reiss \& Hottinger, 1984; Hallock, 1988). The optimum development of the modern nurnmulitids is between 50 and $70 \mathrm{~m}$ (Murray, 1973; Reiss \& Hottinger, 1984; Hallock, 1988), whereas the optimum development of Eocene pustulose nummulitids in the Jaisalmer Basin in India has been estimated at around $20 \mathrm{~m}$ (Singh, 1984).

The nummulitid populations in the studied samples are characteristically dominated either by large B-forms or by small A-forms. Aigner $(1982,1983,1985)$ has argued that this is a function of hydrodynamic sorting, and that B-form dominated populations are characteristic of autochthonous and A-form dominated populations of allochthonous accumulations. This has been disputed by various others authors (e.g. Wells, 1986). However, it seems reasonable to interpret A-form dominated assemblages associated with planktonic foraminifera as allochthonous. The latter fall in the 'toe-of-slope' field of a ternary plot of foraminiferal 'morphogroups' (Fig. 4). These assemblages are believed to have been transported along with fine clastic material on account of their high internal porosity and low threshold. Present-day populations of the nummulitid Operculina bartschi have been reported similarly transported into deep water off New Caledonia (Debenay, 1988).

\section{Domanda Shale Member (Kirthar Formation)}

Lithology ranged from mudstone to bioclastic limestone.
Micropalaeontological and palynological analyses were undertaken on two samples (56 and 57).

Results. The microfauna is impoverished, and includes only rare benthonic and planktonic foraminifera, ostracods, gastropods, and bivalve, echinoid and miscellaneous macrofossil debris. The benthonic foraminifera include Lituolida (lituolids), Miliolida (Alveolina elliptica, alveolinids, miliolids, soritids) and Rotaliida (anomalinids). The ostracods include Cyprideis sp.

The palynoflora is also impoverished, and includes only rare marine dinoflagellate cysts and terrestrially derived pollen and spores. The dinocysts includ ?Achomosphaera sp., ?Areoligera, Diphyes colligerum (?D. ficusoides), Glaphyrocysta sp.

Discussion. Stratigraphy - A 'mid' Middle Eocene age was indicated by the occurrence of the larger benthonic alveolinid foraminifer Alveolina elliptica (Lutetien Basal - Moyen (2) of Schaub, 1981; calcareous nannoplankton Zones NP15-NP16/17 of Martini, 1971). Published information suggests an essentially Middle-?Late Eocene age for the Kithhar Formation (see, for instance, Gill, 1953; Nagappa, 1959; Latif, 1961; Khan, 1967; Siddiqui, 1971; Samanta, 1972, 1973; Dorreen, 1974; Kureshy, 1978a,b, 1985b).

The Domanda member appears to be associated with the essentially regressive global third-order (?eustatically mediated) sequence TA3.4 of Haw et al. (1987).

Palaeoenvironmental interpretation-Microfaunal evidence points to a low-energy back-bank lagoon characterized by Miliolida. The depth of depositional environment is difficult to determine, because it would have been determined not by the foraminifera themselves but by the photosynthetic algal symbionts to which they acted as host. Modern Alveolinella quoii contains photosynthetic B-3 diatoms which restrict it to between 15 and $75 \mathrm{~m}$, with optimum development between 30 and $50 \mathrm{~m}$ (e.g. Reiss \& Hottinger, 1984; Murray, 1973; Hallock, 1988).

\section{Pir Koh Limestone Member (Kirthar Formation)}

Lithologies ranged from laminated shale through mudstone to limestone. Micropalaeontological, nannopalaeontological and palynological analyses were undertaken on five samples $(54,55$, 144, 147 and 149).

Results. The microfauna is moderately rich and diverse, and includes benthonic and planktonic foraminifera, calcareous algae, ostracods, radiolarians, and miscellaneous macrofossil debris. The benthonic foraminifera include Lituolida (Clavulinoides sp.), Miliolida (miliolids, soritids), Nodosariida (Lenticulina sp.), Buliminda (Brizalina sp., eouvigerinids), smaller Rotaliida (Cibicidoides sp., discorbids, Gyroidina sp., Nonion sp.) and larger Rotaliida (Assilina exponens, A. sp., Asterocyclina spp., Dictyoconoides cooki, $D$. sp., Discocyclina spp., Linderina spp., Nummulites beaumonti, $N$. nanngoelani ( $N$. mamilla auctt.),. $N$. cf. obtusus, $N$. spp., Sphaerogypsina sp.). The planktonic foraminifera (Globigerinida) include Globigerina (Subbotina) ex gr. linaperta, ?Globigerinatheka sp., globigerinids/ tenuitellids, Globorotalia (Acarinina) ex gr. bullbrooki, G. (A.) spp., G. (Morozovella) spinulosa, G. (M.) spp., G. (Turborotalia) centralis, Hantkenina spp., Orbulinoides beckmanni and Truncorotaloides topilensis. The calcareous algae include Distichoplax biserialis. The ostracods include Alocopocythere sp., bairdiids, cyprids, Cytherella sp., Krithe sp., Occulticythereis sp. and 
trachyleberidids.

The nannoflora is also moderately rich and diverse, and includes Braarudosphaera bigelowi, Chiasmolithus grandis, Coccolithus pelagicus, Discoaster barbadiensis, D. saipanensis, Helicosphaera sp., Sphenolithus moriformis, S. predistensus and S. spp.

The palynoflora is also moderately rich and diverse, and includes marine dinoflagellate cysts and terrestrially derived pollen and spores. The dinocysts include Achomosphaera sp., ?Areoligera sp., Cordosphaeridium sp., ?Diphyes sp., Impletosphaeridium sp., ?Leptodinium sp., ?Nematosphaeropsis sp., Phthanoperidinium sp., Spiniferites sp. and Wetzeliella sp.

Discussion. Stratigraphy - A 'mid' Middle Eocene age is indicated by the occurrences of the larger benthonic nummulitid foraminifera Assilina exponens and Nummulites beaumonti, (Lutetien Moyen - Biarriatzien of Schaub, 1981; calcareous nannoplankton Zones NP15-NP18 of Martini, 1971), the planktonic foraminifera Globorotalia (Acarinina) ex $\mathrm{gr}$. bullbrooki (Zones P8b-P12 of Blow, 1979) and Orbulinoides beckmanni (P13), and the calcareous nannofossils Chiasmolithus grandis (calcareous nannoplankton Zones NP11-NP17 of Martini, 1971) and Sphenolithus predistensus (NP17-NP24). Published information suggests an essentially Middle-?Late Eocene age for the Kirthar Formation (see, for instance, Gill, 1953; Nagappa, 1959; Latif, 1961; Khan, 1967; Siddiqui, 1971; Samanta, 1972, 1973; Dorreen, 1974; Kureshy, 1978a,b, 1985b).

The Pir Koh Member appears to be associated with the essentially transgressive global third-order (?eustatically mediated) sequence TA3.5 of Haq et al. (1987).

Palaeoenvironmental interpretation - Microfaunal evidence points to a range of carbonate platform and associated basinal sub-environments.

\section{Drazinda Shale Member (Kirthar Formation)}

The dominant lithology is mudstone. Micropalaeontological and palynological analyses were undertaken on five samples (47, 49, 51, 164 and 165).

Results. The microfauna is moderately rich and diverse, and include benthonic and planktonic foraminifera, ostracods, gastropods, and bryozoan, echinoderm and miscellaneous macrofossil debris. The benthonic foraminifera include Miliolida (Dentostomina sp., Pyrgo sp., Quinqueloculina sp.), Nodosariida (Fissurina sp.), Buliminida (Brizalina sp., Stainforthia sp.), smaller Rotaliida (Anomalinoides sp., discorbids, elphidiids/nonionids, Eponides sp.) and larger Rotaliida (Assilina sp., Heterostegina sp., Nummulites beaumonti, N. nanngoelani ( $N$. mamilla auctt.), Operculina sp., Rotalia). The planktonic foraminifera (Globigerinida) include Chiloguembelina cubensis, Globigerina praebulloides, G. (Subbotina) cf. inaequispira, Globorotalia (Acarinina) spp., G. (Turborotalia) cf. opima nana and Truncorotaloides libyaensis. The ostracods include Alocopocythere transcendens, brachycytherids, cyprids, Cytherella sp., Cytherelloidea sp., cytherurids, Gyrocythere exaggerata, Krithe sp., Paijenborchella sp., Pontocypris sp., Quadracythere (Hornibrookella) sp., Stigmatocythere luminaria, thaerocytherids, trachyleberidids and Xestoleberis cf. globosa.

The palynoflora is also moderately rich and diverse, and includes marine dinoflagellate cysts and terrestrially derived pollen and spores. The dinocysts include Achomosphaera sp.,
Areoligera sp., Cordosphaeridium sp., Selenopemphix nephroides, Spiniferites $\mathrm{sp}$. and Wetzeliella $\mathrm{sp}$.

Discussion. Stratigraphy - A late Middle Eocene age is indicated by the occurrences of the larger benthonic nummulitid foraminifer Nummulites beaumonti (Lutetien Moyen - Biarriatzien of Schaub, 1981; calcareous nannoplankton Zones NP15NP1 8 of Martini, 1971) and the planktonic foraminifera Globigerina praebulloides (no older than Zone P14 of Blow, 1979) and Truncorotaloides libyaensis (P10-P14). Published information suggests an essentially Middle-?Late Eocene age for the Kirthar Formation (see, for instance, Gill, 1953; Nagappa, 1959; Latif, 1961; Khan, 1967; Siddiqui, 1971; Samanta, 1972, 1973; Dorreen, 1974; Kureshy, 1978a,b, 1985b).

The Drazinda Member appears to be associated with the essentially regressive global third-order (?eustatically mediated) sequence TA3.6 of Haq et al. (1987).

Palaeoenvironmental interpretation - Microfaunal evidence points to a range of carbonate platform and associated basinal sub-environments.

Palynofloral evidence (the prevalence of the cinocysts Selenopemphix and Wetzeliella) points to a proximal or regressive environment (see, for instance, Harland, 1983; Islam, 1984; Wrenn \& Kokinos, 1986; Bohacs, 1993).

\section{Chitarwata Formation}

The dominant lithology was mudstone. Palynological analyses were undertaken on two samples (166 and 173).

Results. The in situ palynoflora is impoverished, and included only rare freshwater algae (Pediastrum) and terrestrially derived pollen (alder (Alnus), hazel (?Corylus), hemlock (Tsuga), pine (Pinus) and sundry flowering-plant (angiosperm) and grass (Gramineae) pollen) and spores (Deltoidospora, Laevigatosporites, Verrucosisporites).

Discussion. Stratigraphy - No conclusions can be drawn with regard to age. Regional evidence indicates Oligocene.

Palaeoenvironmental interpretation-Palynological evidence points toward a continental environment characterized by a forested (?montane) hinterland. Published information indicates a shallow marine environment for the essentially age-equivalent Muree Formation (Bossart \& Ottiger, 1989). These formations collectively can be regarded as representing a diachronous foreland basin megasequence younging from northeast to southwest.

\section{Siwalik Group}

The dominant lithogy was mudstone. Palynological analyses were undertaken on two samples (159 and 163), both of which were barren. No conclusions can be drawn with regard to age or depositional environment. Published information indicates a Neogene-Pleistogene age and a range of continental depositional environments (see, for instance, Gill, 1953).

\section{CONCLUSIONS}

The results of palaeontological analyses of samples from sections from the Northern Sulaiman Ranges in Pakistan are in keeping with previously published information (though in some cases, including that of the prospective Kirthar Formation, significantly more refined). They enable placement of most of the sampled lithostratigraphic units in a global bio- and 
sequence-stratigraphic framework. The limestones appear to be associated with essentially transgressive global sequences, the shales with essentially regressive sequences.

Palaeoenvironmental intinterpretations indicate a range of depositional settings from continental through shallow marine to basinal. A number of shallow marine carbonate platform subenvironments are recognized over the Palaeocene-Eocene section (essentially back-bank lagoon, bank and fore-bank).

\section{Manuscript received August 1994 Manuscript accepted September 1994}

\section{REFERENCES}

Aigner, T. 1982. Event stratification in nummulite accumulations and in shell beds from the Eocene of Egypt. In Einsele, G. \& Seilacher, A. (Eds) Cyclic and Event Stratification, 248-262. Springer, Berlin.

Aigner, T. 1983. Facies and origin of nummulitic buildups: an example from the Giza Pyramids Plateau (Middle Eocene, Egypt). Neues Jahrbuch, fur Geologie und Palaontologie, Abhandlungen, 166: 347-368.

Aigner, T. 1985. Biofabrics as dynamic indicators in nummulite accumulations. Journal of Sedimentary Petrology, 55: 131-134.

Banks, C. J. \& Warburton, J. 1986. 'Passive-Roof duplex geometry in the frontal structures of the Kirthar and Sulaiman Mountain Belt, Pakistan. Journal of Structural Geology, 8: 229-237.

Benjamini, C. 1981. Limestone and chalk transitions in the Eocene of the Western Negev, Israel. In Neale, J. W. \& Brasier, M. D. (Eds) Microfossils from Recent and Fossil Shelf Seas, 205-213. Ellis Horwood, Chichester.

Blow, W. H. 1979. The Cainozoic Globigerinida. E. J. Brill, Leiden.

Bohacs, K. M. 1993. Source quality variations tied to sequence development in the Monterey and Associated Formations, Southwestern California. In Katz, B. J. \& Pratt, L. M. (Eds) Source Rocks in a Sequence Stratigraphic Framework, 177-204. American Association of Petroleum Geologists Studies in Geology, No. 37.

Bossart, P. \& Ottiger, R. 1989. Rocks of the Murree Formation in Northern Pakistan: indicators of a descending foreland basin of Late Paleocene 10 Middle Eocene Age. Ecologae Geologicae Helvetiae, 82(1).

Bou Dagher, M. 1987. The Stainforthiidae (Foraminifera) in the Late Palaeocene and Early Eocene of Tunisia. Bulletin des Centres de Recherches Exploration-Production Elf-Aquitaine, 11: 133-152.

Brown, J.C. \& Dey, A. K. 1975. The Mineral Fuels of the Indian Subcontineni and Burma. Oxford University Press, Oxford.

Buxton, M. W' N. \& Pedley, H. M. 1989. A standardised model for Tethyan Tertiary carbonate ramps. Journal of the Geological Society, 146: $746-748$.

Das Gupta, S. K. 1975. A revision of the Mesozoic-Tertiary stratigraphy of the Jaisalmer Basin, Rajasthan. Indian Journal of Earth Sciences, 2: $77-94$.

Debenay, J.-P. 1988. Dynamic sedimentation at the outlet of the Bay of Prony, New Caledonia: dispersion of lutites and the tests of the foraminifera Operculina bartschi Cushman. Revue de Paleobiologie, Volume Special (Proceedings of the Third International Symposium on Benthonic Foraminifera, Geneva, 1986): 765-770.

Decrouez, D. \& Lanterno, E. 1979. Les 'Bancs a Nummulites' de l'Eocene Messogeen et leurs Implications. Archives des Sciences, Geneve, 32: 6?-94.

Dorreen, J. M. 1974. The western Gaj River section, Pakistan, and the Cretaceous-Tertiary boundary. Micropaleontology, 20: 178-193.

Eames, F. E. 1952. A contribution to the study of the Eocene of Western Pakistan and Western India. Quarterly Journal of the Geological Society, 107: 159-200.

Ghose, B. K. 1977. Paleoecology of the Cenozoic Reefal foraminifers and algae -- a brief review. Palaeogeography, Palaeoclimatology, Palaeoecology, 22: 231-256.

Gill, W. D. 1953.a. Fauna and facies in the Bhadrar Beds of the Punjab Salt Range, Pakistan. Journal of Paleontology, 27: 824-844.

Hallock, P. 1988. Diversification on algal symbiont-bearing foramini- fera: a response to oligotrophy? Revue de Paleobiologie, Volume Special (Proceedings of the Third International Symposium on Benthonic Foraminifera, Geneva, 1986): 789-797.

Hallock, P. \& Glenn, E. C. 1986. Larger foraminifera: a tool for Paleoenvironmental interpretation analysis of Cenozoic carbonate depositional facies. Palaios, 1: 55-64.

Haq, B. U., Hardenbol, J. \& Vail, P. R. 1987. Chronology of fluctuating sea-levels since the Triassic. Science, 235: 1153-1165.

Haque, A. F. M. M. 1956. The foraminifera of the Ranikot and Laki of the Nammal Gorge, Salt Range. Memoirs of the Geological Survey of Pakistan, 5: 1-300.

Harland, R. 1983. Quaternary dinofagellate ctysts from holes 548 and 549A, Goban Spur (Deep Sea Drilling Project Leg 80). Initial Reports of the Deep Sea Drilling Project, 80: 761-766.

Hemphill, W. R. \& Kidwai, A. H. 1973. Stratigraphy of the Bannu and Dera Ismail Khan Areas, Pakistan. United States Geological Survey Professional Paper, 716-B.

Henson, F. R. S. 1950. Cretaceous and Tartiary reef formations and associated sediments in the Middle East. American Association of Petroleum Geologists Bulletin, 34: 215-238.

Islam, M. A. 1984. A study of Early Eocene palaeoenvironments in the Isle of Sheppey as determined from microplankton assemblage composition. Tertiary Research, 6: 11-21.

Jadoon, I. A. K., Lawrence, R. D. \& Lillie, R. J. 1994. Seismic data, Geometry, evolution and shortening in the active Sulaiman fold- and thrust-belt of Pakistan southwest of the Himalayas. American Association of Petroleum Geologists Bulletin, 78: 758-774.

Keller, G. 1988. Biotic turnover in benthic foraminifera across the Cretaceous-Tertiary boundary at EI Kef, Tunisia. Palaeogeography, Palaeoclimatology, Palaeoecology, 66: 153-171.

Khan, M. A., Ahmed, R., Haza, H. A. \& Kemal, A. 1986. Geology of petroleum in Kohat-Potwar Depression, Pakistan. American Association of Petroleum Geologists Bulletin, 70: 396-414.

Khan, M. H. 1967. Time-hiatus at the Oligocene/Eocene boundary in Sind. Pakistan Journal of Scientific and Industrial Research, 10: 287295.

Kureshy, A. A. 1978a. The biostratigraphic correlation of sedimentary basins of West Pakistan. Annales des Mines et de la Geologie, 28: 327336.

Kureshy, A. A. 1978b. Tertiary larger foraminiferal zones of Pakistan. Revista Espanola de Micropaleontologia, 10: 467-483.

Kureshy, A. A. 1984. The foraminiferal stratigraphy of the Dunghan Formation, Pakistan. In Oertli, H. (Ed.) Benthos '83 (Proceedings of the Second International Symposium on Benthic Foraminifera, Pau, April 1983), 345-348. Pau \& Bordeaux; Elf Aquitaine, Esso REP \& Total CFP.

Kureshy, A. A. 1985a. The foraminiferal stratigraphy of the Laki Formation (early Eocene) of Pakistan. Geologie Mediterraneenne, 11: $231-236$

Kureshy, A. A., 1985b. The Eocene-Oligocene foraminiferal boundary of Pakistan. Geologie Mediterraneenne, 11: 225-230.

Latif, M. A. 1961. The use of pelagic foraminifera in the subdivision of the Paleocene-Eocene of the Rakhi Nala, West Pakistan. Geological Bulletin of the Punjab University, 4: 29-100.

Luterbacher, H.-P. 1984. Paleoecology of foraminifera in the paleogene of the southern Pyrenees. In Oertli, H. (Ed.) Benthos '83 (Proceedings of the Second International Symposium on Benthic Foraminifera, Pau, April 1983), 389-392. Elf Aquitaine, Esso REP \& Total CFP, Pau \& Bordeaux.

Martini, E. 1971. Standard Tertiary and Quaternary calcareous nannoplankton zonations. In Farinacci, A. (Ed.) Proceedings of the Second Planktonic Conference, Rome, 739-785. Edizioni Tecnoscienza, Rome.

Moody, R. T. J. 1987. The Ypresian carbonates of Tunisia - a model of foraminiferal facies distribution. In Hart, M. B. (Ed.) Micropalaeontology of Carbonate Environments, 89-92. Ellis Horwood, Chichester.

Murray, J. W. 1973. Distribution and Ecology of Living Benthic Foraminiferids. Heinemann Educational, London.

Nagappa, Y. 1959. Foraminiferal biostratigraphy of the CretaceousEocene succession in the India-Pakistan-Burma region. Micropaleontology, 5: 145-192.

Pautal, L. 1987. Foraminiferal assemblages of some Early Eocene 
Environments (Bays) from the Northern Corbieres, France. In Hart, M. B. (Ed.) Micropalaeontology of Carbonate Environments, 74-81. Ellis Horwood, Chichester.

Philobbos, E. R. \& Keheila, E. A. 1979. Depositional environments of the Middle Eocene in the area south-west of Minia, Egypt. Annals of the Geological Survey of Egypt, 9: 523-550.

Racey, A. 1994. Palaeoenvironmental significance of larger foraminiferal biofabrics: implications for petroleum exploration. Abstracts, Middle East Geosciences Conference, Bahrain, 1994: xxiii.

Raxa, H. A., Ahmed, R., Alam, S. \& Ali, S. M. 1989a. Petroleum zones of Pakistan. Pakistan Journal of Hydrocarbon Research, 1: 1-20.

Raza, H. A., Ahmed, R., Ali, S. M. \& Alam, S. 1989b. Petroleum prospects; Sulaiman sub-basin, Pakistan. Pakistan Journal of Hydrocarbon Research, 1: 21-59.

Reiss, Z. \& Hottinger, L. 1984. The Gulf of Aqaba: Ecological Micropaleontology. Springer, Berlin.

Samanta, B. K. 1972. Planktonic foraminiferal biostratigraphy of the Early Tertiary of the Rakhi Nala section, Sulaiman Range, West Pakistan. Journal of the Geological Society of India, 13: 317-328.

Samanta, B. K. 1973. Planktonic foraminifera from the PalaeoceneEocene Succession in the Rakhi Nala, Sulaiman Range, Pakistan. Bulletins of the British Museum (Natural History), Geology, 22: 421482.

Schaub, H. 1981. Nummulites et assilines de la tethys Paleogene: taxinomie, phylogenie et biostratigraphie. Memoires Suisses de Paleontologie, 104-106.
Serra Kiel, J. \& Regaunt, S. 1984. Paleoecological conditions and morphological variation in monospecific banks of nummulites: an example. In Oertli, H. (Ed.) Benthos '83 (Proceedings of the Second International Symposium on Benthic Foraminifera, Pau, April 1983), 557-563. Elf Aquitaine, Esso REP \& Total CFP, Pau \& Bordeaux.

Siddiqui, Q. A. 1971. Early Tertiary ostracoda of the family Trachyleberididae from West Pakistan. Bulletins of the British Museum (Natural History), Geology, Supplement, 9.

Singh, N. P. 1984. Addition to the Tertiary biostratigraphy of Jaisalmer Basin. Petroleum Asia Journal (April, 1984): 106-128.

Smout, A. H. 1957. A note on the larger foraminifera and ostracoda of the Ranikot from the Nammal Gorge, Salt Range, Pakistan. Records of the Geological Survey of Pakistan, 8: 49-60.

Versteegh, G. J. M. 1994. Recognition of cyclic and non-cyclic environmental changes in the Mediterranean Pliocene: a palynological approach. Marine Micropaleontology, 23: 147-183.

Wells, N. A. 1986. Biofabrics as dynamic indicators in nummulite accumulations - discussion. Journal of Sedimentary Petrology, 56: 318-320.

Wilson, J. L. 1975. Carbonate Facies in Geologic History. Springer, Berlin.

Wrenn, J. H. \& Kokinos, J. P. 1986. Preliminary comments on Miocene through Pleistocene dinoflagellate cysts from DeSoto Canyon, Gulf of Mexico. In Wrenn, J. H., Duffield, S. L. \& Stein, J. A. (Eds) Dinoflagellate Cyst Biostratigraphy. American Association of Stratigraphic Palynologists Contributions Series (No, 17) 169-225. 